Bu makaleye atıfta bulunmak için/To cite this article:

KÖYLÜ, M. (2021). An Evaluation on the Effect of Sultan Vahideddin on the Leaving of Mustafa Kemal Pasha

to Anatolia. Atatürk Üniversitesi Sosyal Bilimler Enstitüsü Dergisi, 25 (Özel Sayı), 313-327.

\title{
An Evaluation on the Effect of Sultan Vahideddin on the Leaving of Mustafa Kemal Pasha to Anatolia
}

Murat KÖYL $\ddot{U}^{(*)}$

Abstract: Although Mustafa Kemal tried to explain various possible solutions by meeting with the Sultan Vahideddin on several occasions over time, he found a desperate sultan without any will. There was no leader capable of planning and implementing a great organization that could save the country from invasion. However, Mustafa Kemal knew the enemy very well. He knew that this enemy, which he had defeated earlier in Gallipoli, would destroy the Turkish Homeland no matter what. The solution could be nothing more than a total struggle with the handful of forces at hand, utilizing all the assets. According to Mustafa Kemal, "perishing is better for a nation rather than living as a prisoner". While all these historical events are obvious, some historians are insistently portraying Sultan Vahideddin as a hero. Is Sultan Vahideddin a "traitor", who collaborated with the British during the armistice period; or is he a degenerate pursuing for the continuation of his reign, as Mustafa Kemal Pasha said in his speech? Is he a hero who started the War of Independence that assisted Mustafa Kemal Pasha to Anatolia? The purpose of this study is to evaluate the influence of Sultan Vahideddin on Mustafa Kemal Pasha's transition to Anatolia, by examining the relations between Vahideddin and Mustafa Kemal Pasha since October 30, 1918.

Keywords: Vahideddin, Mustafa Kemal Pasha, armistice, national struggle, treason

\section{Mustafa Kemal Pașa`nın Anadolu’ya Geçișinde Sultan Vahdettin in Etkisi Üzerine Bir Değerlendirme}

Öz:Mustafa Kemal, zaman içinde çeşitli vesilelerle Padişah Vahideddin ile görüşerek, olabilecek muhtelif çözüm yollarını anlatmaya çalışsa da, karşısında iradesiz ve çaresiz bir sultan bulmuştu. Ülkeyi işgalden kurtarabilecek büyük bir organizasyonu planlayı, uygulayabilecek yetenekte bir lider yoktu. Oysa Mustafa Kemal düşmanı çok iyi tanıyordu. Gelibolu da yendiği bu düşmanın ne kadar taviz verilirse verilsin, Türk Yurdu `nu yok edeceğini çok iyi biliyordu. Çözüm, elde kalan bir avuç kuvvetlerle, varını yoğunu ortaya koyarak topyekûn bir mücadeleden başka bir şey olamazd. Zira Mustafa Kemal e göre " bir millet esir olarak yaşamaktansa, yok olsun daha iyiydi". Gerçekte Sultan Vahideddin mütareke döneminde İngilizlere işbirliği yapan bir "hain" midir vel veya Mustafa Kemal Paşa`nın Nutuk`ta ifade ettiği gibi, sadece kendi saltanatının devamını isteyerek soysuzlaş mıdır? Yoksa Mustafa Kemal Paşa yı Anadolu ya görevlendirerek Milli Mücadele fitilini ateşleyen bir kahraman midır? Çalıșmanın amacl; 30 Ekim 1918`den itibaren Vahidettin `nin işgalciler ile Mustafa Kemal Paşa arasindaki ilişkileri inceleyerek, Mustafa Kemal Paşa 'nın Anadolu ya geçişi üzerine Sultan Vahideddin in etkisini değerlendirmektir.

Anahtar Kelimeler: Vahideddin, Mustafa Kemal Paşa, mütareke, milli mücadele, hainlik

\footnotetext{
${ }^{*}$ Doç. Dr., Çağ Üniversitesi Hukuk Fakültesi Kamu Hukuku Bölümü (e-posta: murat.koylu86@gmail.com) (D) ORCID ID.https://orcid.org/0000-0001-7759-7675

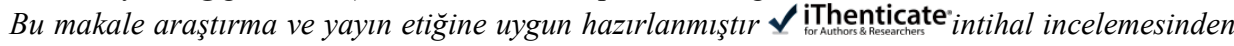
geçirilmiştir.
} 
Makale Gelis Tarihi: 13.12.2020

Makale Kabul Tarihi: 20.11.2021

DOI:10.53487/ataunisosbil.839922

\section{Introduction}

Sultan VI. Mehmet Vahideddin, the 23th of Sultan Abdülmecit's 30 children, ascended the throne after the bombing of Istanbul by Allied Forces on 4 July 1918, following his brothers (Murat V, Abdülhamit Han II, Sultan Mehmet Reşad V) He tried to make peace many times under any circumstances, as soon as he was enthroned (Çetiner, 2017). When he learned the conditions of the armistice to be made by the Entente States towards the end of the First World War, Vahideddin told İzzet Pasha: "I guess that the friendship and benevolent politics of the British in the east that continued for centuries will not change. We can get benefits from them later (Özkaya, 1981)". With this idea, he surrendered to United Kingdom, and with it, the fate of the six-century old world empire was left to the mercy of British politics.

The Armistice Period, established after the Mondros Armistice Treaty, is a four year depression period: from when it was signed (30 October 1918), to the abolition of the Ottoman reign (1 November 1922) (Tunaya, 2003). Except for the armistice signed by Germany, other armistice agreements signed by Bulgaria, Austria, Hungary and the Ottoman Empire were similar. There were articles about occupation of troop dispatch points,demobilization of the armies, dispersing of weapons and ammunition, release of prisoners of Entente without reciprocity, giving the control of communication and transportation lines to the Entente, and termination of relations between the Alliance States (Akbulut, 2005). Although the Ottoman armistice seemed to be lighter in comparison to other allied states, in practice, it was the beginning of a Turkish national disaster (Keskin, Yuvalı vd., 1995). The Armistice of Mudros meant the disappearance of the Ottoman Empire (Eroğlu, 1990). Although the armistice was normally signed as a layover of arms, the arms were retaken, whenever the Entente felt necessary (Balkaya, 2008).

According to Lord Curzon, the British Prime Minister at the time; "the Turks are a problem for Europe and they should be imprisoned in distant Asia". However, the Allied Powers wanted to solve this situation by finding a formula, which would not worry the mostly Muslim European colonies that could be affiliated with the Caliphate. The most plausible formula was the "Vatican Proposal". According to this formula, "Istanbul and the Straits would been taken under international status and France and England will have a dominant influence in the administration together. "The new capital of the Turkish Government will be in Asia Minor, but the Sultan will remain the leader of all Muslims and Istanbul will remain the capital of Islam" (Criss, 1994).

The basic idea of the Allied Powers was that the Ottoman Empire would continue to exist in control of the Entente as a small state squeezed into Anatolia as a result of the implementation of the Mondros Armistice. 
Consequently, what desired was "a puppet state whose strings were in the hands of imperialism." In order to achieve their goals, the Entente States occupied the Bosphorus on 15 November 1918. On December 8, they established a military administration, where the port, tram, gendarmerie and police services were under strict control.

Mustafa Kemal explained the armistice and its aftermath in his speech as follows;

"The allience that included the Ottoman Government had been defeated in the Great War. The Ottoman Army had been crushed on every front. An armistice had been signed under severe conditions. The prolongation of the Great War left the people exhausted and impoverished. Those who had driven the people and the country into the war had now fled and cared for nothing but their own safety. Vahdettin, the degenerate occupant of the throne and the Caliphate, was seeking for some despicable way to save himself. He was like a servant and agreed to every proposal to protect himself (Kemal, 2016).

As soon as Mustafa Kemal set foot in Samsun after leaving Istanbul, he only had one decision in mind: "establishing a fully independent Turkish State within national borders." He held the belief that the liberation of the Turkish Homeland, can only be achieved with a total national struggle against the invasions. Hundreds of years of Ottoman reign had no meaning for him, for the concessions made to the western imperialists had only delayed the inevitable end. These concessions at the end, made the Turkish people crushed by wars, become poor, and left them in a small piece of Anatolia. Now, Turkish people were facing total destruction.

\section{After the Armistice of Mudros, Sultan Vahideddin and the Istanbul Government}

Following the signing of the Mondros Armistice, the Unionist leaders Enver, Cemal and Talat Pashas left Istanbul on a German warship at midnight on November 2-3, 1918. Sultan Vahideddin, who was close to the Unionists until then, suddenly changed his side and became an anti-Unionist. Rauf, Fethi, Cavit, and Hayri began to suggest to the Grand Vizier Ahmet İzzet Pasha to end their duties in the cabinet at once. Sultan Vahideddin had seen it as an opportunity to regain power after a long time, with the exclusion of the Unionists. He immediately took action and sent the President of the Assembly Ahmet Riza to İzzet Pasha and demanded the resignation of Unionist Rauf, Fethi, Cavit and Hayri. He demanded that if this request was not fulfilled, the cabinet should resign altogether and a new government should be formed by excluding the Unionist ministers from the cabinet. However, Izzet Pasha stated that Sultan Vahideddin was not authorized to give such orders as per the constitution Thus, with the support of Fethi and Rauf, he rejected the order. (Kinros, 2018). The following conversation had taken place with Rauf:

“... Rauf also stated that in Bulgaria and Austria, which fell into turmoil after the armistice, those who suffered the most from were the leaders of those countries. Hearing this, the sultan became anxious and his hands started to tremble. His cigarette fell out of his mouthpiece. The aide took the cigarette from the floor and placed it on a tray. The Sultan stood up, saying that he disagreed with Rauf's thoughts. This indicated that the meeting was over. The Sultan looked at Rauf and said the following with a sense of firmness, "Gentlman, our nation is like a flock of sheep." "They want a shepherd. Here, I am this shepherd ... ". Rauf did not say anything. 
He left with a reluctant salute with his right hand. Evidently, the sultan, in the role of a shepherd, intended to gather his flock and drive it directly to the allies' corral (Kinros, 2018)."

Yeni Istanbul Newspaper wrote the following (published November 16, 1918): "There is no more fortuneless Sultan in Ottoman history than Sultan Mehmet Vahideddin. The people should gather around this cherished crown in deep awe (Sarihan, 1982)." On the other hand, the Times Newspaper (London, November 19, 1918) wrote that the Vahideddin, will aid the Entente States in maintaining peace and order in Turkey.

On November 13, 1918, the navy of the Entente States crossed the Dardanelles and anchored in front of the Dolmabahce Palace. This started to cause concerns to Sultan Vahideddin. As a result, on November 23, 1918, he moved from Dolmabahce Palace to Yildiz Palace, especially because of the Greek warship anchored in front of Dolmabahce, which was feared to be linked with a conspiracy(Akşin, 1992).

The Sultan saw great importance in being the Caliph of all Muslims. Hence, he hoped that the only way to protect his caliphate and reign was to take appeal to the good intentions of the occupiers, not angering them, and allying the British to gain their support. With that, the British would gain the support of the caliph in ruling the majority Muslim areas of their empire. Spanish writer Jorge Blanco Villalta evaluated this issue as follows: "The heart of the Ottomans (Sultan Vahideddin and the Istanbul Government) was not interested in the Turkish people, rather their happiness and respect for their glorious traditions. Vahideddin's new ally (England) got everything they wanted from him. Lloyd George was now rubbing his hands in satisfaction because the Eastern Question had been resolved for the benefit of England (Villalta, 1982)".

As soon as Sultan Vahideddin moved to Yildiz Palace (November 24, 1918), he begun to offer an olive branch to the British, whom he considered as allies, through the Londonbased Daily Mail newspaper (Akşin, 1992): "The love and admiration I have for the British nation is inherited from my father Abdülmecit. I will do my best to strengthen the friendship between our countries."

Sultan Vahideddin's approach to the British is particularly evident in the letter below from Tom Hohler, one of the officials of the British High Commissioner in Istanbul, addressed to George Kidston, Chief of the East Desk at the British Foreign Office , on December 5, 1918 (IDA, 19.01.1919):

"It will be a pity if the current conditions are not to end the administration by the Turks. I am ready to see this city under any government as long as it is not the Turkish one, because they are not even able to administer pig stalls. The Turks know very well that they are defeated all completely. Their organizations are fragmented, defeated; they themselves are in misery... Istanbul is experiencing the days of occupation. The administration here is bad enough to disgust every Englishman ..."

French and volunteer Armenian troops under the command of Lt Col Louis Romieu entered Adana on December 21, occupying military facilities and arresting civilianmilitary notables. At the same time, the British were pressuring Sultan Vahideddin to shut down the Parliament, which had raised its voice against the invasions (Akşin, 1992, s. 134). Although there was an objection among many deputies, which accused the 
Ottoman administration of staging a coup, Vahideddin complied with this request of the British and by interpreting the 7 articles of the Constitution as his own authority, he dissolved the Parliament on December 21 (Bayar, 1972) (Gökbilgin, 1965). Sultan Vahideddin's chief secretary Ali Fuat wrote in his memoirs that the Sultan told him the following afterwards: "Foreigners do not watn this National Assembly to be acknowledged. You must act to protect your right to life. They are saying that if you do not take the necessary action, you will risk your life (Türkgeldi, 1951)".

Rear Admiral Richard Webb (Deputy High Commissioner of the British in Istanbul) wrote the following in a private letter to Sir Ronald Graham (Deputy Undersecretary of the British Ministry of Foreign Affairs) on 19 January 1919 (IDA, 19.01.1919):

"Although we did not occupy the country on surface, we are now appointing or removing governors from their posts, managing the police, inspecting their media, entering their prisons and free Greek and Armeniansregardless of the crimes. We keep the railways in tight control and confiscate everything we want... Our policy is based on the sharp end of the bayonet... As long as the Caliph is at our disposal, we have the means of control over the Islamic World... As you know, the Sultan wishes to place us here..."

Vahideddin wanted the British control not only in Istanbul, but in every corner of Anatolia. However, the political situation was not suitable for this (Sonyel, 1986, s. 44). Regarding this, the following secret telegram was sent from the British Headquarters in Istanbul to the British Military Intelligence Chief on December 16, 1918 (IDA, 16.12.1918):

"Sami Bey, on behalf of the Sultan and the Minister of Foreign Affairs, came to the General Headquarters today and said that he wants the United Kingdom to take over the administration at at the earliest time. If he said we waited until peace is achieved, it would be too late. Sami Bey also wants a British administration to be established in Arabia. He wishes assigning British officers to the interior affairs of the country for inspection purposes and dispatching of the British officials to assist administration. Turkish soldiers in the Caucasus will be placed under our (British) order; every officer we do not want will be dismissed."

An English supporter Damat Ferid Pasha, who was married to Sultan Vahideddin's older sister Mediha Sultan, had worked as a clerk at the British Embassy. As soon as he took the post of the government, he visited Richard Webb (British Deputy High Commissioner) on March 9, 1919. In this meeting, he said: "My lord, and my hopes are based on God and British rule" (IDA, 09.03.1919).

With his arrival, Damat Ferid Pasha immediately resumed the detentions of the officers and deputies he accused under the pretext of the so-called Armenian Genocide. This was an accusation against the Unionists and resulted in the appointment of a British adviser to each governor (Şimşir, 1972).

Ferid Pasha went to the Yildiz Palace with a sudden decision, in order for the Sultan to approve an urgent decree on April 9, 1919. The decree was about the execution of Kemal, the Deputy Governor of Yozgat and the District Governor of Boğazkesen. In addition, the Gendarmerie Commander Tevfik was also sentenced to 15 years in prison with the same decree. The same was attributed to both patriots: disbanding multiple armed Armenian gangs who were preparing to revolt in their regions and kill the Turks. 
They were sending the Armenians back to their regions without any mistreatment. Moreover, this was in accord of current orders and existing laws. A death sentence was issued before a proper defence from Kemal. This was because Damat Ferid Pasha wanted to give confidence to the British and the occupation forces (Çetiner, 2017).

\section{Conversations Between Sultan Vahideddin and Mustafa Kemal Pasha}

Mustafa Kemal Pasha, while resisting the enemy in the mountains in Aleppo, had received the news of the armistice and the order of ceasefire, on October 30, 1918 (Kinros, 2018). Turkish people were indifferent at the beginning of the occupations. Although there were smallresistance to occupations, these were not popular. The majority was bowing to the fate, thinking to avoid punishment from the occupation forces. Some people migrated inland from Western Anatolia and the settlement of these immigrants started to pose a separate problem. As the wars that lasted for years, people had begun to hate the otherwise sacred military service and placed an important portion of the responsibility of wars especially on officers. For this reason, officers working in the National Force had to wear civilian clothes to prevent any reaction (Aybars, 2002).

In addition, invaders started to assert reasons based on the classic accusation campaigns against the Turks. According to these, Turks were not civilized, the Unionists were some foolish and unscrupulous guys, who drowned the country in a long state of suffering. In this respect, the armistice would be "the first of the remedies applied to Turkey" (Tunaya, 2003).

In accordance with the conditions of the armistice, and after Liman Von Sanders was called to Istanbul; on the day that the Mondros Armistice was signed, Mustafa Kemal Pasha was appointed to the Lightning Armies Group Command (ATASE):

He immediately went to the headquarters in Adana. The German general greeted him with his usual formal courtesy. They lit cigarettes, one by one. At the request of Mustafa Kemal, Liman von Sanders ordered two coffees. They drank their coffee thinking about the past and future in silence. That night, the skies of Adana were lighting by the flames of the ammunition depots that the Germans sat on fire. At the departure meeting of German and Turkish officers, a German general ended his speech praising their past friendship in arms, saying, "We have been defeated." "Everything is over for us now." Mustafa Kemal said in his speech, "The war may been over for our allies." "But the war that interests us, our War of Independence, only begins now" (Kinros, 2018).

Mustafa Kemal Pasha, who started his new duty, wrote to the Grand Vizier Ahmet Izzet Pasha in his telegram dated November 6, 1918; "Without taking measures to resolve the disputes for the conditions of the armistice, if the armies are demobilized, it will not be possible to prevent British requests" (ATASE).

However, the Ottoman Government considered it hard to intervene or oppose the invasions that started under the leadership of the British. The government thought that being tolerant could gain favors in the future peace negotiations. Thus, Ahmet İzzet Pasha had the opinion that these pressures could be reduced a little by some protests in the society (Türkmen, 2018). 
Mustafa Kemal Pasha, who was dismissed after the Lightning Armies Group Command was abolished, came to Istanbul from Adana on 13 November 1918. He believed that it would be beneficial to seek solutions through diplomatic and political means in order to save the country from the harsh conditions brought by the conditions of the armistice.

On the day that the Allied Navy entered Istanbul (the morning of 13 November 1918), Mustafa Kemal Pasha got off the train at Haydarpaşa Station. He was very upset when he saw the Entente Fleet and Averof, the famous destroyer of the Greeks, in the Bosphorus. While crossing with the Kartal steamboat with his friend Doctor Rasim Ferit, who came to meet him, Mustafa Kemal said "I shouldn't have come to Istanbul. What I should do is to look for any ways to return to Anatolia! ". He followed that with his famous sentence: "They will leave, as they have come" (İğdemir, 1969).

Istanbul seemed to be crushed under the weight of sad, hopeless and disaster: the "patronage" of the Entente States. Everbody was saying "Now they can do whatever they want to us" in fear. A cold, dark winter had begun. There was no coal. Trams were not working. Bosphorus ferries were few and sparse. Since the main streets were half bright and the side streets were dark, the thieves and robbers flourished after dark, nobody could go out without carrying a gun. The police was few; nobody had confidence in them anyways because they were corrupt. Money was devaluated and the food prices had skyrocketed. The Turks were even claiming that they were not Turks by throwing their fez, in order to find work alongside the Allied Forces that entered the city (Kinros, 2018).

The situation of the British, who started to invade the country using the terms of the ceasefire, and the Istanbul Government, who ignored the warnings, had worried Mustafa Kemal Pasha, but it did not intimidate him. In order to solve this situation, he liked to talk to Sultan Vahideddin about his warnings that he could not tell the Government about, and express his ideas openly as a "precaution" in order to save the state from the impending dangers. The idea of meeting with the Sultan occured to him because of his trip to Germany with the Sultan in December 1917.

In October 1917, when Emperor Wilhelm II came to Istanbul for the third time, he invited Sultan Mehmed Reşad to the German General Headquarters. The acceptance of this invitation and the visit had thus become inevitable. Sultan Reşad decided to send the Crown Prince Vahideddin to Germany instead of going himself, because he was too old and sick to travel by train.

It was decided that Mustafa Kemal Pasha, who came to Istanbul after leaving Adana and appointed as the Commander-in-Chief, would accompany the Crown Prince Vahideddin on this trip and he was asked whether he would accept it or not. Seeing this trip as very important, Mustafa Kemal Pasha stated his acceptance with pleasure. Naci (Eldeniz) Pasha (who was a colonel at the time), who was fluent in German and was a teacher of Mustafa Kemal from the Military School, also accompanied the crown prince as a translator.

After the train left Istanbul, Mustafa Kemal Pasha sat in the compartment that was prepared for him. Once the journey began, Vahideddin invited Mustafa Kemal to his 
compartment while the train was traveling through Thrace. Mustafa Kemal Pasha described Vahideddin's words about him in this meeting in his memoirs (Atay, 1955):

"Excuse me, His Holiness Pasha, they did not explain to me with whom I was traveling until a few minutes ago. However, upon the information I received just after the departure, I realized that I was in absentia (without seeing his face) with a commander whom I knew and appreciated very much. I know you very well. All your achievements in Ariburnu and Anafartalar are completely known. You are a commander who saved Istanbul and the country, I am glad and proud to be traveling together."

He was very impressed with his conversation with. Vahidettin: "I thought that this person should be smart. When we first met in Istanbul, the Crown Prince showed a strange influence to the reasons and sharia (reasons and conditions), which is easy to understand by those who know that era. After leaving Istanbul, he saw no harm in showing his true personality as he felt completely free and realized that the people who he is talking with are trustable. Accordingly, I also hoped that I could explain all the circumstances and necessities to him and even make him agree to take action on some grounds."

Mustafa Kemal Pasha was aware how important it is for the future of the country to communicate correctly with Vahideddin, who was a member of the dynasty and the future sultan, during a verydifficult situation of the country. In Ottoman traditions, every prince candidate for the sultanate was given a very good education in case he could become the sultan one day. It was clear that Vahideddin was not ignorantand aware of what was happening. After the signing the armistice, he made an appointment from the palace through the Naci Pasha who was also his teacher at the academy. He wanted to talk about the future of the country and share his ideas (Sarıhan, 1982). Mustafa Kemal Pasha met with Sultan Vahdeddin on November 22, 1918 at the Friday Prayer (Akşin, 1992):

Vahideddin had acted before him. He said that: "I am sure that army commanders and officers respect you greatly. Can you guarantee that they will not take ant action against me?" Such a question had surprised Mustafa Kemal. After some thought, "Does our master know for sure about any military action to be taken by the army against the throne?" he asked. The Sultan closed his eyes. Then he repeated his question. "I have to say that I only came to Istanbul a few days ago" Mustafa Kemal replied. "So I don't know the situation very well. However, I assure you, I do not think there is any reason for the commanders and officers in the army to plot against you and your reign." Vahideddin very seriously said that, "I meant not only for today, but tomorrow as well (Kinros, 2018)."

The Crown Prince tried to protect his own position, and was worried that the army would make an attempt to replace him. The defeated and crushed Sultan thought that Mustafa Kemal Pasha had great army support and Vahdeddin was thinking of securing his future by drawing Mustafa Kemal Pasha to his cause, who was respected by the general and army officers as the hero of Anafartalar.

Encouraged by the invasion attempts initiated by the British, the Greeks in the Eastern Black Sea region especially in Samsun, started attacking the Turkish villages by forming gangs and carried out actions to break public order. These gangs were receiving weapons and ammunition from Greek ships that patrolled the Black Sea alongside British. Turks living in the region started to fight by arming among themselves, in order to protect their lives, property, and chastity.. As a result, the British landed a battalion on Samsun on 
March 3, 1919, and a division in Amasya. While the apparent task of these British troops was to maintain order in Samsun, they in fact were taking measures that would create an infrastructure for a future puppet Greek state. This was going to be done by suppressing the Turks in the region and supporting the activities of the Greek Pontus community. On the other hand, the "council" transformations initiated by the Communist Russia were rapidly moving from the Caucasus to the Black Sea. The "sovietization" in the region created a situation that contrasted the British policies and had to be prevented immediately. The British Occupation Forces Commander-in-Chief in Istanbul, Admiral Calthorpe, gave a note to the Ottoman Foreign Ministry on April 21, 1919 (Jaeschke, 1971):

Admiral Calthorpe demanded: "My military situation is not good in the Erzurum, Erzincan, Bayburt and Sivas regions (demobilization and delivery of arms is slow). According to what I learned from various sources, in these sections. they established councils (Soviets) throughout and recruited soldiers under the supervision of the councils and the army. This should be stopped immediately, the councils should be prevented to recruit, order should be restored in Samsun, and the weapons should be collected and handed over ", (Müderisoğlu, 2019).

The government immediately began to prepare for sending a mighty commander as an inspector to the region as a precaution, not to anger the British or violate the terms of the armistice. However, most of the successful war commanders were accused of being Unionists, and some of them were already arrested and imprisoned by the British on the false grounds, such as their involvement in Armenian related events and mistreatment of British prisoners of war. Therefore, the army inspector had to be appointed as a general who the British could not object to. The fact that Mustafa Kemal Pasha, who was not getting any results from the political activities he carried out in Istanbul and had already made the plans to start a movement by from Anatolia, made the government's task easier. Especially, since the British knew that Mustafa Kemal Pasha had opposed some of the Germans' actions during the war, they did not object his appointment for the task.

The appointment decree of Mustafa Kemal Pasha was approved by Sultan Vahideddin on April 30 (Takvim-iVekayi, 1919). Before moving to Samsun, Mustafa Kemal Pasha wanted to meet with Sultan Vahideddin to learn his thoughts about to the task in Anatolia. When Mustafa Kemal Pasha visited thegovernment in Babiali on May 15, he learned about the Greek occupation of Izmir and then went to Yildiz Palace in a hurry (Bayur, 1963). Under the shadow of the cannons of the the Entente ships, Vahideddin said to him briefly:

"Pasha, Pasha, you have served the state a lot until now; all of these are now memories... gone down in history. Forget these... Actually, your service may be more important than all of them. Pasha, you can save the state.." Showing the cannons of the British battleships: "You see, I hesitate to imagine how to save the country and the nation. I hope the nation will gather its mind and become awake. Both me and the nation should save themselves from this difficult situation."

According to the American author Laurence Evans, (which is also the subject of our study): "The aim of the Sultan was to drive Kemal away from the capital (Evans, 1965)." 


\section{Evaluation and Conclusion}

Discussions in the society about Vahideddin who was clearly identified as "degenerate" by Mustafa Kemal Pasha, continue even today. Some of the allegations in particular:

"He is the most unfortunate of the Ottoman sultans. That is why he was labeled as a traitor. But he is not a traitor, he is patriotic like all other Ottoman sultans (Atsiz, 1955)."

"The creator of the national awakening movement and the one who sent Mustafa Kemal Pasha to Anatolia for this purpose is directly Vahideddin ... If there were no Vahideddin, there would be no Turkish War of Independence and thus, no liberation (Kısakürek)."

"Sultan Vahideddin planned a resistance movement in Anatolia, against the dangers looming on the horizon and he planned it carefully, despite the occupation forces around him. As a result of, he sent one of his aide, Mustafa Kemal Pasha, to Anatolia, equipped with great authority and means (Misıroğlu, 1992)."

"It was the Sultan who sent Mustafa Kemal to Anatolia with extraordinary powers for the national struggle. You know, Sultan Vahideddin, who was described to us as a traitor. startingfrom the first grade of primary school (Vakkasoğlu, 2017).

"The hero for the start of the liberation movement of Anatolia is Sultan Vahideddin. ... Sultan Vahideddin did not betray his homeland, on the contrary, he was the one betrayed in return for what he had done for this country (Ceylan).

"Vahideddin gave 400.000 Gold and 400.000 Paper Liras to Mustafa Kemal Pasha to start the War of Independence ..."

The Claim that Mustafa Kemal Pasha was Sent by Vahideddin to Anatolia to "Start the War of Independence": Mustafa Kemal Pasha got to know Sultan Vahideddin during his trip to Germany, which started on December 15, 1917. Here, they established familiarity with their conversation. During his time in Istanbul, he had two more private meetings before the last one on May 15, 1919. Vahideddin, who wandered like a sleepwalker to avoid palace intrigues, thought that he knew Mustafa Kemal very well, a person that could sacrifice everything to protect his sultanate and caliphate. For this reason, Mustafa Kemal marks Vahideddin`s words: "Pasha, you can save the state!" and explained the true intention behind them (Atay, 1955):

"I was stunned by these last words. I wonder if Vahideddin had spoken to me sincerely? He was Vahideddin, he was trying to save his state and his sovereignty by seeking contact with the lowest ranked person of foreign governments. Did he regret all he had done? Does he now understand that he had been cheated? How could I expect a high and noble action from the man that I knew about the tendencies and dishonesty in his crown prince and sultanate? Homeland needs saving, I can do this if I want. How? I immediately decided: Vahideddin meant to say that we had no power. Our only option was to comply with the politics of those who occupy Istanbul. My mission to go to Samsun is to settle the issues they (the occupiers) complain about. If I convince the country and the people that this policy was correct and if I put the Turks who oppose in line, and of course also if I please the occupiers, it would fullfill the wishes of Vahideddin." 
An Evaluation on the Effect of Sultan Vahideddin on the Leaving of

\section{The Claim that Vahideddin gave 400.000 Gold and 400.000 Paper Liras to Mustafa Kemal Pasha to Start the War of Independence:}

The first claim is from Nihal Ats1z: "Vahidettin gave Mustafa Kemal Pasha 40,000 gold for organization. Most of this money was obtained by selling the valuable racehorses he hadfor a long time (Atsiz, 1955)."

Another claim is from Kadir Misıroğlu: "Sultan Vahideddin obtained the necessary money for this task by selling his personal horses. Sultan Vahideddin, who was a very good rider, bred very precious race horses. He gave the 40,000 gold obtained in this way to Mustafa Kemal Pasha (Vakkasoğlu, 2017)."

Another claim is from Mevlanzade Rifat: "Mustafa Kemal Pasha was paid 100,000 liras from the state budget in a disguised manner (Mevlanzade, 2017).

It was Prince Mahmut Şevket who brought this idea to the extreme: "Vahideddin gave Mustafa Kemal Pasha the broadest of powers and the necessary money. According to what I know, he constantly sent money to the pasha, both through himself and various governmental means, especially during the Ali Riza Pasha's government. The amount of this money is 400,000 gold. (Şevket, 1967)."

According to Müderisoğlu; When Vahideddin can give such a large amount of money from the state budget to Mustafa Kemal Pasha,the following should be concluded: there must be records in state accounts. However, such a document could not be found in the Ottoman State archives (Müderisoğlu, 2019).

On the other hand, according to Müderrisoğlu; An Ottoman gold pound is 7.2 grams. Accordingly, the weight of the 40,000 gold lira allegedly given by Vahideddin from his own pouch is $288 \mathrm{kilos}$, and the weight of the 360,000 gold lira allegedly given from the state budget is $2.592 \mathrm{kilos}$, the weight of 400,000 gold liras is 2,880 kilos. The weight of 400,000 paper lira is approximately $560 \mathrm{~kg}$. In this case, the total weight of the gold and banknotes claimed to been given to Mustafa Kemal Pasha is 3,440 kilograms. When placed in forty-pound standard crates used for carrying loads in those years,. 400,000 paper liras can fit in approximately 35 standard boxes in volume. How can he carry such a load with himself at all times and make them transported first to Samsun, then to Erzurum via Havza, Amasya, Tokat, and Sivas; and then to Ankara, the starting place of the War of Independence (Müderisoğlu, 2019)?

It is the correct thing to judge every event in its own period and evaluate what happened in the historical environment. Vahideddin, who stayed under the shadow of his three older brothers, was perhaps one of the most distant princes from the caliphate and sultanate. Even his older brother Prince Yusuf Izzettin could not bear this heavy circumstances and committed suicide. Vahidettin was seated on the Ottoman throne towards the end of a great war, when the industrial revolution had already changed the destiny of the world and imperialism was at its peak. He had to experience the consequences of the great disaster that the Unionists and Progressivists had dragged the country into, and faced the dire task of solving the great problems at the end of a war he had not started. The war ended, the Ottoman Empire and its allies surrendered and the armistice was signed. The country collapsed economically, the people were daunted, weary, and desperate, walking towards a hopeless future. Vahideddinwas giving the 
impression of a sultan who sees himself as the "shepherd" of this people and tried to find the best way to bring them salvation without letting them caught by the wolves, while aiming to protect the "caliphate and sultanate".

The most basic rule that palace intrigues taught him was that he should not trust anyone. In such an insecure environment, he chose not to bring anyone to power except his relatives (Damat Ferid Pasha and his fellow Tevfik Pasha), whom he even hated. He chose a safe way of administration by closing the assembly and taking decisions himself. There were two major threats to him: The first was the army officers who opposed him and still included Unionists . The other was the occupation forces. He began to come up with plans thinking he could choose one of the two and maintain his position by clashing with the other.

Vahideddin had chosen to fight the army and his opponents, while taking the support and protection of the British. Even the mighty German Empire had surrendered to Britain in a war.Now as an Ottoman who was left alone, it would not be the right course of action to dare fight the British again. According to Vahideddin, the Ottoman Empire, who was the strongest Empire of the World in certain parts of the history, was in a poor and daunted state; who had no other choice but to appeal to the mercy of its enemy. At least, staying as the Caliph of millions of Muslims under the auspices of a great state, ensuring the continuity of the sultanate, and maintaining the existence of the Ottomans, albeit without any real power, was seen as the best solution that could be considered under the circumstances. The prevailing opinion was that it would be better to leave the fate and future of the Anatolian people to the decision of the nations representing civilization.

According to him, what Mustafa Kemal Pasha and those who think like him wanted to do was nothing more than a catastrophe that would bring the country into a greater disaster, annihilation. With an initiated resistance, they would not only anger the Entente States, but also destroy the tolerant and compromising attitude of especially Britain. God forbid - this could even cause the disappearance of the sultanate and caliphate.

Was Sultan Vahideddin a traitor? No Ottoman sultan who came to the sultanate since its establishment could not and did not have been a traitor. However, Vahideddin was the last desperate Ottoman Sultan who thought that a fight against the British, whom Gandhi referred as "The God", would not succeed and result in more dire consequences, and that it would be wiser to gain Britain's protection rather than a struggle with them. His biggest deficiency was that he did not know the Anatolian people beyond the palace / Istanbul. He did not get close enough to measure the patriotism, determination, and resolve of the Anatolian people. Mustafa Kemal Pasha explained the reason for this in his speech (Kemal, 2016):

"Here I must explain a very important point. The Nation and the Army did not have a suspicion at all about the Sultan-Caliph's treachery. On the contrary, on account of century old religion and traditiol, they remained loyal to the throne and its occupant. Seeking a means of salvation under the influence of this tradition, the security of the Caliphate and the Sultanate concerned them far more than their own safety. For them, the idea that the country could possibly be saved without a Caliph and a Sultan was impossible to comprehend. And woe to those who 
ventured to think otherwise! They would immediately be looked down upon as men without faith and patriotism; and as such would have been scorned."

Mustafa Kemal Pasha was a commander who thought differently from Vahideddin and others. He believed that he could form a great power that could resist the invasions and imperialism with a strong determination. He could be the leader, not the "shepherd", of the nation and he made all his attempts on this idea. Because with the idea that " $a$ nation whose freedom is taken away inevitably becomes a slave to other nations", it was the best way to act with the motto of "independence or death" and the nation should choose to fight a struggle that will risk death rather than leave its destiny to the mercy of another nation.

As a result, both leaders had developed their own solutions for the country's salvation. However, they separated from each other with the difference of these solutions. Vahideddin thought to continue the current order by gaining the tolerance and sympathy of the occupiers, by making any concessions that could be given to the invaders, mainly for the continuation of the "historical flow with the habits of tradition". Mustafa Kemal Pasha, on the other hand, believed that the future was in going through a difficult and arduous struggle based on the principle of protecting the national sovereignty and the integrity of the country. Thus, he embarked on a journey that would sacrifice his life to reach victory. The basis of Mustafa Kemal Pasha's belief in victory was from his witnessing the heroic struggle of his nation in defense of the homeland in the battlefieldslike the Dardanelles. He knew about this determination of the people very wellThis is because why Gandhi said, "The Turkish Nation, who is thought to be dead, smashed their coffins on the heads of their murderers during the funeral."

\section{Bibliography}

Akbulut, D. A. (2005). Çöken devlet. Cumhuriyet, 130-138.

Akşin, S. (1992). Istanbul Hükümetleri ve Milli Mücadele. İstanbul.

ATASE. (n.d.). Ankara: Gn.Kur.

ATASE. (n.d.). Ankara: Gn.Kur.

Atay, F. R. (1955). Mustafa Kemal'in Bana Anlattıkları. İstanbul: Hisar Matbaası.

Atsız, N. (1955). Türk Ülküsü. İstanbul.

Aybars, E. (2002). Ístiklal Mahkemeleri. Ankara: Ayraç Yay.

Balkaya, İ. S. (2008). Mütareke dönemi asayişin üç boyutu. Atatürk Yolu Dergisi, 1140.

Bayar, C. (1972). Ben De Yazdım. İstanbul.

Bayur, H. (1963). Atatürk, Hayatı ve Eseri. Ankara.

Ceylan, H. H. (n.d.). Mustafa Kemal Büyük Oyun. Rehber Yay. 
Criss, B. (1994). İsgal Altında İstanbul, İkinci Basım. İletişim Yayınları.

Çetiner, Y. (2017). Son Padişah Vahidettin. Kronik Yayınları.

Eroğlu, H. (1990). Türk Inkilâp Tarihi. Savaş Yayınları.

Evans, L. (1965). United States Policy and the Partition of Turkey (ABD'nin Politikast ve Türkiye'nin Bölünüşü). Baltimore.

Gökbilgin, M. T. (1965). Milli Mücadele Başlarken.

İDA. (09.03.1919). Webb'den İngiltere Dışişleri Bakanlı̆̆g'na gizli telgraf. FO $371 / 4141 / 40280$.

IDA. (16.12.1918). Ingiliz Genel Karargâhindan İngiltere Askeri İstihbarat Şefine gizli telgraf. FO 371/3421/214122.

IDA. (19.01.1919). Webb'den Graham'a özel mektup. FO 371/3411/211362.

İğdemir, U. (1969). Birinci Dünya Savaşı'nda Mustafa Kemal'le Mareşal Falkenhein Arasında Çıkan Anlaşmazlığa Dair Bazı Belgeler. Belleten XXXIII/132, 505-515.

Jaeschke, G. (1971). Kurtuluş Savaşı ile ilgili İngiliz Belgeleri.

Kemal, G. M. (2016). Nutuk. Fark Yayınları.

Keskin, M., Yuvalı, A., A.Öztürk, \& Ekincikli, M. (1995). Türk inkılâbı ve Türkiye Cumhuriyeti tarihi. Ufuk Yaynlar1.

Kinros, L. (2018). Atatürk, Bir Milletin Yeniden Doğuşu. Altın Kitaplar.

Kısakürek, N. F. (n.d.). Vatan Dostu Sultan Vahiddütin. Büyük Doğu Yay.

Mevlanzade, R. (2017). Türkiye İnkllabının İ̧̧ yüzü. Kaknüs Yay.

Mısıroğlu, K. (1992). Osmanoğulları'nın Dramı. Sebil Yay.

Müderisoğlu, A. (2019). Vahdettin'in Kurtuluş Savaşııı Başlatması İçin Mustafa Kemal Paşa'ya 400.000 Altın Ve 400.000 Kağılt Lira Verdiği Gerçek Dışı Bir İddiadır. Retrieved 01 12, 2019, from http://dergiler.ankara.edu.tr/dergiler /45/814/10331.pdf

Özkaya, Y. (1981). Türk İstiklal Savaşı ve Cumhuriyet Tarihi.Ankara Üniversitesi Tıp Fakültesi Yayınları.

Sarıhan, M. Z. (1982). Kurtuluş Savaşı Günlüğü.

Sonyel, S. R. (1986). Türk Kurtuluş Savaşı ve Dış Politika.

Şevket, Ș. M. (1967, 07 06). Tercüman.

Şimşir, B. (1972). Ingiliz Belgelerinde Sakarya'dan İzmir'e. 
An Evaluation on the Effect of Sultan Vahideddin on the Leaving of

Mustafa Kemal Pasha to Anatolia

Takvim-i Vekayi, 5. (1919, 05 05).

Tunaya, T. Z. (2003). Türkiye'de siyasal gelişmeler. İstanbul: Bilgi Üniversitesi Yayınlar1.

Türkgeldi, A. (1951). Görüp İşittiklerim.

Türkmen, Z. (2018). Mustafa Kemal Paşa ve Yıldırım Ordular Grup Komutanlı̆̆ı””. Retrieved 12 04, 2018, from Atatürk Araştırmaları Merkez Başkanlığı:

http://www.atam.gov.tr/dergi/sayi-47/mustafa-kemal-pasa-ve-yildirim-ordularigrup-komutanligi

Vakkasoğlu, V. (2017). Osmanlı'dan Cumhuriyet `te Son Bozgun. Nesil Yay.

Villalta, G. B. (1982). Atatürk. 